\title{
TARIAN “LANGIT-BUMI” REFLEKSI PELAYANAN BULAN BAHASA DAN BUDAYA DI GEREJA MASEHI INJILI DI TIMOR
}

\author{
Henderikus Nayuf \\ Dosen Teologi STT Intim Makassar \\ hendrikusnayuf@yahoo.com.ig
}

\begin{abstract}
The concensus of May to become the month of language in the service of GMIT reflected as a chance to express the identity of local comonity. The exploration through dance and pray constitue psalm and proverb chant in the format of the liturgy. In this format the value of the traditional as the identity of the local community conforotd with the ecclesiastic consencus and the consencus of the nation and state. The culture encounter of the local community need a dialetic media in order to convey the message of the humanityso it will be wedely accepted by the church community. Ethnographic accentuation are use this qualitative method. Beside the library research are use to analyze the result of the research. Through emancipation dialectic, GMIT within supotive reletion between themselves the local governmentsincerely give the local community the change to expessed themselves without worry persistenly as a impact of the contention betweenthe church doctrine and the value of the local tradition from the local community.
\end{abstract}

Key Words: Language Mounth, consencus, local wisdom, exploration, emantipation

\begin{abstract}
Abstrak
Penetapan bulan Mei setiap tahun sebagai Bulan Bahasa dalam lingkup pelayanan Gereja Masehi Injili di Timor (GMIT) dimaknai sebagai wadah yang tepat mengekpresikan identitas masyarakat adat. Eksplorasi nilai-nilai kearifan lokal melalui tarian dan doa merupakan mazmur dan amsal yang dilantunkan dalam format tata ibadah. Dalam format inilah, nilainilai kearifan sebagai identitas masyarakat adat diperhadapkan pada konsensus gerejawi yang tentunya tidak bertentangan dengan konsensus bangsa dan Negara. Perjumpaan identitas masyarakat adat dalam format gerejawi membutuhkan media dialektika agar pesan-pesan kemanusiaan yang menjadi kekuatan masyarakat adat dapat diterima secara luas oleh warga gereja. Metode penelitian yang digunakan dalam tulisan ini adalah metode kualitatif dengan penekanan pada pendekatan etnografi. Di samping itu, pendekatan library research digunakan untuk menganalisa hasil penelitian yang telah dilakukan. Melalui dialektika yang emansipatif, GMIT dalam relasi yang saling menopang bersama pemerintah daerah secara tulus memberi ruang bagi masyarakat adat untuk berekpresi tanpa merasa gundah gulana sebagai dampak dari benturan doktrin gerejawi dan nilai-nilai kearifan masyarakat adat.
\end{abstract}

Kata kunci: bulan bahasa, konsensus, kearifan lokal, eksplorasi, emansipatif 


\section{Pendahuluan}

Secara umum, masyarakat Nusa Tenggara Timur (NTT) dikenal dengan beberapa tarian tradisionalnya. Beragam tarian yang sering digunakan dalam acara-acara adat, maupun dalam acara-acara kenegaraan adalah tarian bonet dari Timor Tengah Selatan (TTS), Timor Tengah Utara (TTU) maupun sebagian Kabupaten Kupang bahkan Kota Kupang dan tarian tebe dari sebagian Kabupaten TTU, Belu dan Malaka. Dalam penelitian terhadap tarian bonet, Ramona Mathias Mae menemukan bahwa melalui bonet masyarakat dapat mengekspresikan dan mengungkapkan perasaan melalui syair dan pantun pada upacaraupacara adat. ${ }^{1}$ Secara praktis, manfaat dari tarian bonet adalah mengajarkan tarian bagi anak-anak secara spesifik untuk kebugaran fisik, kordinasi tubuh, percaya diri dan konsentrasi, melatih komitmen dan disiplin, sosialisasi dan kerja sama tim dan penyaluran emosi. ${ }^{2}$ Studi ini menempatkan tarian bonet sebagai salah satu tarian yang tidak saja berkontribusi bagi relasi sosial, tetapi juga sebagai media pembelajaran. Sementara dalam studi terhadap nilai-nilai dan makna tarian Tebe di Desa Kusa, Kecamatan Malaka Timur, Kabupaten Malaka, Hildegardis Un menjelaskan latar belakang diadakannya tarian Tebe. Menurut Un, tarian Tebe merupakan tarian yang menandakan pergaulan yang akrab di antara warga. Selain itu, menurut Un, tarian Tebe, juga sebagai ekspresi kegembiraan atas keberhasilan atau kemenangan. ${ }^{3}$

Nilai-nilai yang muncul dari kedua tarian di atas adalah persekutuan, persaudaraan, kekerabatan, kerja sama, kebahagiaan dan ucapan syukur. Dari perspektif kekristenan, nilainilai itu merupakan intisari dari iman Kristen. Dalam konteks inilah, Gereja Masehi Injili di Timor (GMIT) memberi ruang bagi tarian-tarian di atas, dan tarian-tarian lainnya untuk menghadirkan kearifan-kearifannya dalam ibadah-ibadah gerejawi. Walau demikian, niat itu diperhadapkan pada dua hal. Pertama, penolakan dari kalangan tertentu dengan alasanalasan yang bersifat alkitabiah. Kedua, ketidaksiapan generasi milenial dalam melakonkan tarian tradisional termasuk bonet dan tebe. Berhadapan dengan kedua hal di atas, maka berbagai upaya terus dilaksanakan oleh GMIT dalam memaknai panggilannya di tengahtengah konteksnya. Salah satu upaya konstitusional adalah bersepakat bersama dalam consensus gereja untuk mengakomodir nilai-nilai budaya dalam liturgi GMIT.

Salah satu hasil keputusan Sidang Sinode (GMIT) ke-31 di Jemaat GMIT Pola, Tribuana, Kalabahi, Alor adalah ditetapkan setiap bulan Mei sebagai bulan bahasa. Penetapan itu tertuang dalam Ketetapan Sinode Gereja Masehi Injili di Timor Nomor 14/TAP/SIN-GMIT/XXXI/2007 tentang Peraturan Ibadah dan Atribut. Dalam bagian penjelasan, secara khusus penjelasan peraturan ibadah dan atribut gereja, dalam bab II:2, point b, 1 dijelaskan, bahwa bulan Mei adalah Bulan Bahasa dalam lingkup pelayanan GMIT.4 Menindaklanjuti hasil keputusan sinode tersebut, maka selama bulan Mei setiap tahun, desain Tata Ibadah diformat untuk memberi ruang kreasi agar nilai-nilai keariafan lokal terakomodir dalam ibadah. Legal standing dari desain ibadah pun secara eksplisit tertuang dalam peraturan tersebut. Artinya, GMIT memberi ruang bagi warganya untuk menata ibadah sesuai dengan konteksnnya.

${ }^{1}$ Ramona Mathias Mae, Pengembangan Model Tarian Bonet, untuk Kebugaran Jasmani dalam Pembelajaran Penjasorkes di Sekolah Dasar, dalam Jurnal Keolahragaan, 5 (1), 2017, 81 - 89, http://journal,uny.id/index.php.jolahraga

2 Mae, Pengembangan Model Tarian Bonet, 82.

${ }^{3}$ Hildegardis Un, Nilai-nilai dan Makna Tarian Tebe di Nusa Tenggara Timur, Desa Kusa, Kecamatan Malaka Timur, Kabupaten Malaka, dalam Simki-Pedagogia, Vol. 01 No. 08, Tahun 2017, (Kediri:Universitas PGRI Kediri, 2017), 2

4 Ketetapan Sinode Gereja Masehi Injili di Timor Nomor 14/TAP/SIN-GMIT/XXXI/2007 tentang Peraturan Ibadah dan Atribut (Kupang: Majelis Sinode GMIT, 2007), 4. 
Selama dua tahun terakhir (2018-2019), saya mengamati pelaksanaan ibadah selama bulan Mei begitu atraktif dengan menampilkan tarian, busana dan dekorasi gedung ibadah sesuai dengan tema dan konteks setempat. Tema-tema yang dimunculkan setiap minggu selama bulan Mei mempertegas komitmen GMIT untuk memberi ruang bagi nilai-nilai kearifan lokal (local wisdom) dalam rangka membangun kehidupan berjemaat yang memahami identitasnya. Narasi yang dijadikan sebagai referensi pengembangan tata ibadah pun diangkat dari pergumulan yang sementara dihadapi oleh warga GMIT. Persoalannya adalah apakah atraksi yang ditampilkan merupakan ekspresi personal yang dinarasikan secara kolektif, ataukah atraksi-atraksi tersebut hanya bersifat festival? Menghadirkan tarian dalam ibadah GMIT menghadapi dua tantangan besar sebagaimana telah disinggung di atas, yakni kelompok yang menganggap liturgyibadah sebagai sesuatu yang sakral dan karena itu tidak boleh dicampuradukan dengan berbagai unsur budaya. Di samping itu, saya menyaksikan keterlibatan generasi milenial sangat minim.

Beragam tanggapan pun bermunculan. Sebagian besar memberi apresiasi positif. Tetapi ada juga yang memberikan catatan kritis. Pdt. Wanto Menda, jurnalis Berita GMIT dan juga pengelola Website GMIT, menyimpulkan respon warga GMIT terkait pelaksanaan Bulan Bahasa dan Budaya pada tahun 2019. Menurut Menda, respon warga GMIT bervariasi. Ada yang menyatakan liturginya terlalu panjang, terkesan show. Sebagian menyatakan syukur dan terimakasih. ${ }^{5}$ Pendapat warga GMIT juga bervariasi dalam konteks geografis. Bagi warga GMIT di kota-kota, baik kota kecamatan,kota kabupaten dan kota propinsi dengan ciri heterogen, mengeluhkan liturgy yang cukup panjang. Sementara warga GMIT yang ada di desa-desa dengan ciri homogen mengalami kesulitan dalam mengikuti liturgy yang disusun dan diterbitkan oleh Majelis Sinode. Paul Bolla, seorang warga GMIT menuliskan responnya dalam dialek Melayu Kupangdengan judul "Kebaktian ko Pertunjukan." 6 Dialog antara Ba'i Ndu dan Sulabe'I menarasikan suasana bathin warga gereja dalam merayakan bulan bahasa dan budaya. Paul Bola mendeskripsikan suasana praibadah maupun pasca ibadah yang dialamai oleh sepasang suami-istri asal Rote tersebut. Setting lokasi pra-ibadah terjadi di rumah Ba'i Ndu dan Sulabe'i. Ba'I Ndu mengenakan pakaian Rote: selimut, salembang dan ti'ilangga. Paul Bola menggambarkan Ba'I Ndu seperti maneleo dari Rote. Begitu juga Sulabe'i. Hiasan bulan sabit, baju putih dari bahan brokat dan sarung Rote. 7

Ketika sepasang suami-istri yang mengenakan pakaian adat Rote mengikuti ibadah, ternyata Ba'I Ndu tidak sejahtera. Ada sesuatu yang mengganjal. Itulah yang dideskripsikan oleh Paul Bola. Ba'I Ndu, dalam imajinasi Paul Bola, menyatakan,

“Tadi tu gereja ko acara pertunjukan seni... Kebaktian tadi tu lebe banyak menarimenari. Kenapa ko taro dalam ibadah. Dia pung hubungan apa? Trus katong hanya jadi penonton. Batong ni pi gereja bukan pi nonton pertunjukan"; 8 Arti harafiah: (suasana yang dialami di gereja lebih dominan, pertujukan tarian. Apa hubungannya dengan ibadah? Lantas, apa peran jemaat? Apakah hanya penonton? Kita ke gereja bukan pergi untuk menonton pertunjukan).

Suasana ini diresponi oleh Sulabe'I dengan menyatakan, "Itu kan bagus... Apalagi para penari pake pakian daerah dan menari tarian adat. Mama rasa itu bagus." Ba'I Ndu kemudian menyimpulkan dua hal: pertama, dalam ibadah terjadi perjumpaan dengan Tuhan. Karena itu perlu keterlibatan jemaat. Jika jemaat terlibat, maka terjadilah persekutuan yang

\footnotetext{
${ }^{5}$ Wawancara dengan Wanto Menda (39 tahun), Kupang 15 Juni 2019

6 Paul Bola, Kebaktian ko Pertunjukan, dalam sinodegmit.or.id, 18 Mei 2019, 1.

7Ibid.

8 Paul Bola, Kebaktian ko..., 1.
} 
baik. Kedua, persekutuan dalam ibadah menyangkut keterlibatan secara fisik, hati dan jiwa. Jika ingin membuat pertunjukan, desain acaranya harus berbeda.

Tanggapan-tanggapan tersebut yang menjadi latar belakang studi ini. Tanggapantanggapan tersebut memperkuat observasi yang saya lakukan selama dua kali perayaan bulan budaya dan bahasa, yakni pada bulan Mei 2018 dan bulan Mei 2019. Secara khusus untuk tahun 2019, saya mewawancarai beberapa anggota jemaat dan pendeta jemaat di beberapa lokasi. Terdapat tiga pertanyaan yang akan dibahas dalam studi ini. Pertama, apa makna bulan budaya dan bahasa bagi warga gereja. Kedua, bagaimana membangun dialog antara nilai-nilai kearifan lokal (local wisdom) di wilayah GMIT yang menjunjung tinggal hidup dalam kekerabatan dengan gaya hidup milenial yang menempatkan kemajuan teknologi informasi sebagai kekuatan relasional? Ketiga, apa relevansi pelaksanaan bulan budaya dan bahasa bagi kemandirian teologi GMIT?

\section{Metode Penelitian}

Untuk meramu semua data yang dikumpulkan maka penulis menggunakan pendekatan kualitatif dengan cara melakukan analisis etnografis. Dalam studi-studi terhadap antropologi agama dan linguistik, analisis etnografis dijadikan sebagai meta (menuju-melalui, mengikuti) dan hodos (jalan, cara, arah) ${ }^{9}$ untuk mendekati pokok kajian. Melalui analisis etnografi, tulisan ini kemudian memberi penekanan pada peran the others dalam membangun nilai-nilai kemanusiaan di GMIT secara khusus dan Nusa Tenggara Timur (NTT) bahkan dunia secara umum.

\section{Hasil dan Pembahasan}

\section{GMIT Mengakui Keragaman Bahasa dan Budaya}

Salah satu butir dalam Pengakuan Iman GMIT (PI-GMIT) adalah "Kami mengaku, karena Roh Kudus, Alkitab menjadi Firman Allah... Firman itu tersimpan dalam kata-kata manusia." 10 Butir pengakuan ini dilandasi pada kenyataan bahwa salah satu konteks yang sangat menonjol di GMIT adalah keragaman suku, bahasa, tradisi dan budaya. Salah satu poin dalam draft rumusan yang kemudian disahkan oleh Sidang Sinode GMIT ke-30 melalui Surat Ketetapan GMIT No. 11/TAP/SIN-GMIT/XXX/2003 tentang Pengakuan dan Pengajaran GMIT, yaitu: "GMIT terus bergumul untuk mengaku imannya kepada Tuhan Yesus Kristus agar pengakuannya itu semakin bermakna dalam konteks pelayanannya, GMIT mewarisi beragam bentuk penghayatan akan Sang Pencipta dan ajaran hikmat dari budaya-budaya lokal. Warisan ini telah menghidupi dan membimbing masyarakat adat jauh sebelum Injil diberitakan di Nusa Tenggara. Tradisi lokal ini pun mengandung kesaksian terhadap anugerah Allah dalam penciptaan-Nya. Oleh karena itu, dalam kesetiaannya kepada tradisi yang am dan dengan jiwa merangkul tradisi lokal, GMIT mengungkapkan jati dirinya dalam sebuah Pengakuan Iman."11

Rumusan pengakuan ini hendak menjelaskan bahwa perayaan bulan bahasa dan budaya pada setiap bulan Mei merupakan pengakuan atas keragaman yang dimiliki oleh GMIT. Keragaman tersebut kemudian menempatkan GMIT sebagai gereja yang harus terbuka terhadap berbagai nilai yang ada dalam masyarakat yang beragam tersebut. Meniadakan keragaman nilai yang dimiliki oleh GMIT justru akan melemahkan elemenelemen fundamental dari pelayanan GMIT itu sendiri. A. Eddy Kristiyanto dalam

${ }_{9}$ Nyoman Kutha Ratna, Metodologi Penelitian, Kajian Budaya dan Ilmu Sosial Humaniora Pada Umumnya (Yogyakarta: Pustaka Pelajar, 2016), 84.

10 Henderikus Nayuf, Allah Merumuskan Diri-Nya, Kajian Filsafat - Teologis tentang Pengakuan Iman GMIT dan Relevansi Trinitarian bagi Kemandirian Teologi di GMIT (Makassar: STT INTIM, 2009 ), 91.

11 Nayuf, Allah Merumuskan..., 86. 
refleksinya terhadap munculnya pengakuan iman menyatakan, bahwa credo atau pengakuan berkaitan dengan aktifitas autentik kreatif gereja. Unsur hakiki credo adalah ekspresi apa yang dihayati (dialami) oleh umat Allah. ${ }^{12}$ Itu berarti ekpresi umat Allah tidak dibatasi hanya pada rutinitas ibadah yang bersifat framed - dibingkai. Pengakuan iman pun tidak hanya sebatas mengucapkan Pengakuan Iman Rasuli. Tetapi, ekspresi umat Allah mesti melampaui rutinitas tersebut. Pengakuan iman mesti dikonkritkan melalui pengakuan akan kepelbagaian umat Allah yang mengaku tersebut. Pengakuan iman tidak hanya diucapkan oleh kelompok umat yang homogen. Pengakuan iman mengejawantahkan nilai-nilai yang dirumuskan dalam Pokok-pokok Eklesiologi GMIT, secara khusus pada bagian yang berbicara tentang hubungan GMIT denga budaya lokal.13

Suara Gembala Majelis Sinode GMIT (MS-GMIT) dalam rangka Bulan Bahasa dan Budaya tahun 2019 menegaskan keragaman tersebut. Merujuk data pada Kantor Bahasa Nusa Tenggara Timur (NTT), MS-GMIT secara konkrit menyebutkan bahwa terdapat 60 bahasa daerah dalam wilayah GMIT. Begitu juga terdapat keragaman budaya yang menjadi ciri khas GMIT. Keragaman budaya yang sangat menonjol dan kemudian menjadi ciri khas adalah keragaman motif tenunan. Keragaman bahasa dan budaya ini merupakan bukti bahwa Allah sudah lebih dahulu hadir dan bekerja dalam budaya, sejarah dan agama suatu masyarakat untuk kebaikan masyarakat itu. Ini berarti tidak ada budaya, sejarah dan agama suatu masyarakat pun yang berdiri di luar jangkauan pemeliharaan dan pemerintahan Allah. ${ }^{14}$

Keragaman ini pun terkonfirmasi melalui penyusunan tata ibadah yang dipersiapkan oleh Unit Pembantu Pelayanan (UPP) Liturgi dan Teologi Majelis Sinode. Pada minggu pertama, 5 Mei 2019, tema yang dimunculkan adalah "Tuhan Allah dalam Bahasa Manusia (Keluaran 3:13-15). Tema ini kemudian dielaborasi berdasarkan etnis Alor-Pantar. ${ }^{15}$ Sapaan awal dalam Tata Ibadah mengangkat sebuah upaya mekanai bahasa manusia yang berdampak pada khidupan. Cerita ini diangkat dari Puntara-Pantar Barat. Kisahnya tentang Kalamburi (kekuatan angkara murka) dan Bumanema (kekuatan yang baik). Dalam sebuah peperangan, bumanema mengalahkan kalamburi. Kalamburi terpecah menjadi dua batu. Kedua batu tersebut dipercayai sebagai tempat bertahtanya roh-roh jahat yang selalu membuntuti manusia. Sementara bumanema digambarkan sebagai pinang wangi yang melambangkan tabiat orang yang berbudi luhur, suka melayani.

Pada minggu ketiga, tema yang diangkat adalah "Budaya yang tunduk pada Kehendak Allah" (Efesus 5:1-21). Konteks Sabu-Rajua menjadi lokus dalam elaborasi tata ibadahnya. Siklus kehidupan masyarakat Sabu-Raijua dinarasikan pada pembukaan ibadah. Ritual puru goho (sadap nira) pada musim kemarau dan ritual djalli ma (pembersihan dan penanaman ladang menjadi gambaran tentang Sabu-Raijua yang sangat tergantung pada alam ciptaan Allah. Hasil tanah bermakna religius ketika manusia meyakini Allah sebagai

${ }^{12}$ A. Eddy Kristiyanto, Rumusan dan Teologi Credo dalam Josep Ferry Susanto (Ed.) Credo dan Relevansinya, Ulasan Komprehensif Rumusan Iman Kristiani (Jakarta: Obor, 2014), 1, 3.

${ }^{13}$ Pokok-pokok Eklesiologi GMIT (Kupang: Majelis Sinode GMIT, 2011), 44-46.

${ }_{14}$ Ebenhaizer I. Nuban Timo, Sidik Jari Allah dalam Budaya, Upaya Menjajaki Makna ALLAH dalam Perangkat Budaya Suku-suku di Nusa Tenggara Timur (Maumere: Ledalero, 2005), ix.

${ }^{15}$ Semua Materi Tata Ibadah sejak Minggu Pertama hingga minggu terakhir selama perayaan Bulan Bahasa dan Budaya diakses melalui sinodegmit.org.id dan kirimkan melalui WA grup Pendeta.Tata ibadah diterbitkan oleh Unit Pembantu Pelayanan Teologi dan Ibadah, Majelis Sinode GMIT, 2019. 
pemberi berkat dan memberi identitas budaya bagi manusia yang berelasi dengan alam secara aktif. ${ }^{16}$

Minggu keempat, 26 Mei 2019 mengambil tema "Mengubah Kebiasaan Dunia." Etnis Timor-TTS diberi penghormatan sebagai lokus dalam elaborasi tata ibadah. Penutupan Bulan Bahasa dan Budaya, 30 Mei 2019 dirangkaikan dengan Hari Kenaikan Yesus Kristus. Melalui UPP Liturgi dan Teologi, GMIT kembali mempertegas pengakuan akan keragaman bahasa dan budaya melalui elaborasi multi etnis: Kupang, Helong, Amarasi, Fatuleu dan Amfoang dalam tata ibadah penutup tersebut. Tema yang diangkat adalah "Hidup dalam kuasa Kenaikan Yesus ke Sorga."

Melalui tema dan keterlibatan unsur bahasa dan budaya dalam tata ibadah selama satu bulan menunjukkan bahwa GMIT tidak hanya mengaku imannya dalam keragaman bahasa dan budaya, tetapi menjadikan bahasa dan budaya sebagai sarana perjumpaan yang memberi dampak bagi warga GMIT.

\section{Mengomunikasikan Pesan Local Wisdom}

Pesan yang menguat dalam perayaan Bulan Bahasa dan Budaya adalah komunikasi etnik. Karena itu, dalam bagian ini, penulis akan mendalami makna komunikasi etnik yang digunakan untuk menyampaikan pesan GMIT mengenai kekayaan bahasa dan budaya. Pesan-pesan kearifan lokal dianalisis secara paremiologis. Paremiologis adalah sebuah metode ilmiah untuk mengeksplorasi nilai-nilai atau sistem keyakinan masyarakat yang tercermin dalam ungkapan yang dimiliki masyarakat tersebut. ${ }^{17}$ Nilai-nilai dalam masyarakat disampaikan secara metaforik dengan menggunakan gaya pepatah atau peribahasa. Dalam konteks ini, nilai-nilai kearifan disampaikan melalui perilaku dan komunikasi. Artinya, perilaku dan komunikasi dapat dijadikan sebagai media untuk menyampaikan pesan-pesan yang telah dihidupi oleh komunitas masyarakat. Bahasa dan budaya yang dimiliki GMIT termasuk dalam kategori ini.

Dalam prolog Tata Ibadah yang dikeluarkan oleh Unit Pembantu Pelayanan (UPP) Teologi dan Ibadah, perilaku dan komunikasi masyarakat adat sangat menguat. Narasinarasi yang disampaikan dalam prolog merupakan "pesan langit" yang menggunakan "bahasa bumi" agar dapat diterima, dimaknai dan dihidupi oleh warga GMIT yang ada di bumi Nusa Tenggara Timur (NTT), minus Sumba dan sebagian wilayah Nusa Tenggara Barat (NTB). Para penutur atau pemilik cerita menggunakan pendekatan metaforik maupun paralelismus dalam menyampaikan pesan-pesan ilahi kepada manusia. Jadi, narasi-narasi dalam prolog dalam tata ibadah semacam, a way of life-nya kehidupan masyarakat yang diangkat dari nilai-nilai budaya mereka. Sebab, nilai-nilai budaya merupakan kumpulan pikiran atau gagasan yang melandasi pola-pola kehidupan dan sistem kepercayaan. ${ }^{18}$

Jika memperhatikan karakter warga GMIT yang hidup secara berkelompok, maka daya kekuatan masyarakat adalah sistem kepercayaan yang tidak bersifat individual, melainkan kelompok. Memperhatikan karakter tersebut, maka mekanisme dalam mengomunikasikan pesan-pesan kearifan adalah bahasa metaforik yang didesain dalam ritual yang sakral. Mekanisme dalam pendekatan paremiologi disebut oleh Venus sebagai gaya metabahasa yang bersifat reflektif dan kritis yang direpresentasikan melalui

${ }^{16}$ Nelci Nafalia Ndolu dan Marsi Bombongan Rantesalu, "Makna Tanah Leluhur Bagi Naomi Berdasarkan Teks Rut 1:1-22," Jurnal Ilmiah Religiosity Entity Humanity (JIREH) 1, no. 1 (2019): 87-98, https:/ /ojs-jireh.org/index.php/jireh/article/view/9. 2015), 1 .

17 Antar Venus, Filsafat Komunikasi Masyarakat Melayu (Bandung: Simbiosa Rekatama Media, 18 Venus, Filsafat...,1. 
peribahasa. ${ }^{19}$ Salah satu kesimpulan dari Yermia Djefri Manafe dalam penelitian terhadap cara pandang (world view) orang Atoni Pah Meto ${ }^{20}$ dalam perspektif komunikasi ritual menyimpulkan bahwa pandangan hidup atau pandangan dunia masyarakat adat Atoni Pah Meto sangat berkaitan dengan orientasi budaya yang mereka anut berdasarkan sistem kepercayaan mereka terhadap hal-hal seperti Tuhan, kemanusiaan, alam, alam semesta dan masalah-masalah filosofis yang berkaitan dengan masyarakat adat Atoni Pah Meto itu sendiri. ${ }^{21}$

Penelitian Manafe terkonfirmasi secara teologis dengan prolog yang dimunculkan oleh UPP Liturgi dan Teologi dalam Tata Ibadah Minggu ke III Bulan Bahasa dan Budaya yang mengangkat kisah tentang "Memahami Nama Allah dalam budaya Atoin Meto." Dalam prolog, terdapat tiga penutur yang mewakili tiga sifat dari Allah, yakni Uis Neno: Apinat ma Aklahat (Allah kekuatan api atau panas dan cahaya Allah; Allah sumber api yang panas; matahari dan cahaya Ilahi. Sifat yang kedua adalah Uis Neno Amoet ma Apakaet (Allah pencipta alam semesta). Sifat ketiga adalah Uis Neno: Alikin ma A'pa'en (Allah pembuka jalan dan pengatur kehidupan). Ketiga sifat ini yang kemudian ditunjukkan oleh Manafe dalam analisanya terhadap world view Atoni Pah Meto. Manafe menyatakan, elemen dasar pola sosialitas manusia tradisional sesungguhnya memberi tekanan pada nilai kebersamaan dan persatuan di dalamnya melingkupi aspek vitalitas manusia untuk hidup dan berkembang. ${ }^{22}$ Aspek itu kemudian dimaknai sebagai karakter manusia dalam memaknai panggilan hidupnya. Salah satu aspek yang sering menjadi perhatian bahkan diyakini sebagai salah "penentu" terciptanya kebersamaan dan persatuan dalam kaitan dengan penegasan Manafe adalah pesan-pesan local wisdom. Kearifan lokal memiliki kekuatan untuk membentuk cara berpikir, cara bertindak dan cara bersosialisasi.

Kekuatan nilai yang dijumpai melalui kearifan lokal dalam struktur masyarakat tradisional secara tidak sadar sesungguhnya terbentuk dari kerangka kosmogonik. Terbentuknya kerangka ini untuk mengingatkan kita, bahwa eksplorasi nilai atau sistem keyakinan masyarakat, sebagaimana disinggung oleh Venus dalam filsafat komunikasi masyarakat Melayu, tidak serta merta hanya pada aspek "meniru dan mengulangi" gerak dan tari semata. Tetapi, ia lebih kepada, meminjam istilah Mircea Eliade, penciptaan kosmik.23 Artinya, aspek universalitas dari keseluruhan semesta alam "direkonstruksi" melalui "tarian langit-bumi" sehingga terjadilah perjumpaan dialogis-pastoral bagi warga GMIT untuk menceritakan hakikat keberimanannya bersama seluruh dimensi gumuljuangnya. Perjumpaan dialogis-pastoral hendak mendengarkan dan juga bergumul bersama warga GMIT dalam arak-arakan mencari keadilan, membangun pendidikan, membalut tanah yang terluka, mendampingi korban human trafficking, dan sederet cerita sukses maupun kisah pilu lainnya.

19 Venus, Filsafat...,1.

${ }^{20}$ Atoni Pah Meto merupakan sebutan bagi masyarakat Timor Barat yang mendiami hampir seluruh Pulau Timor. Secara khusus sebutan ini menunjuk kepada masyarakat tradisional yang ada di wilayah pedesaan. Sebagian besar komunitas Atoni Pah Meto adalah warga GMIT. Lihat Ebenhaizer I. Nuban Timo, Mitos Asal-Usul Nama Pulau Timor, Paper yang diakses melalui https://www.academia.edu/30987663/Mitos_Asal_Usul_Nama_Pulau_Timor. Catatan yang lebih detail mengenai poin ini dapat dijumpai dalam tulisan Gregor Neonbasu, Sebuah Agenda untuk Mengkaji Timor, dalam Gregor Neonbasu (Peny.) Kebudayaan, Sebuah Agenda dalam Bingkai Pulau Timor dan Sekitarnya (Jakarta: Gramedia Pustaka Utama, 2009), 29-30.

${ }^{21}$ Yermia Djefri Manafe, Cara Pandang (World View) Orang Atoni Pah Meto dalam Perspektif Komunikasi Ritual, dalam Jurnal Scriptura, Vol. 6. No. 2, Desember 2016, (Surabaya: UK Petra,2016), 49.

22 Manafe, Cara Pandang... 51.

${ }^{23}$ Mircea Eliade, Mitos-Mitos, Gerak Kembali Yang Abadi, Kosmos dan Sejarah, (Terj. Cuk Ananta; Yogyakarta: IKON TERALITERA, 2002), 25. 
Arak-arakan tersebut mengingatkan kita pada pepatah Latin, “tempus mutantur, et nos mutamur in illid," (waktu berubah dan kita [ikut] berubah juga di dalamnya). Dalam bingkai kehidupan sosial, pepatah ini menekankan bahwa di sela-sela waktu, berkembang juga caracara manusia mengekpresikan diri, yang pada gilirannya juga amat kuat mempengaruhi usaha manusia untuk mencari makna tentang dirinya, tentang orang lain, dan tentang diri bersama orang lain, alam raya dan Yang Ilahi. ${ }^{24}$ Penegasan Neonbasu searah dengan apa yang disampaikan oleh Eliade dalam memaknai kerangka berbudaya manusia yang pada saat bersamaan tidak terpisahkan sebagai makluk beragama. Dua elemen mendasar membingkai manusia dalam pola "tarian langit-bumi." Manusia tidak hanya menari dengan tarian dan kostum dari langit. Tetapi, ia mesti menari tarian dari langit yang juga dapat mengenakan kostum dari bumi. Atau sebaliknya. Menari tarian bumi sambil mengenakan kostum langit. Dalam proses ini, terjadilah dialog yang berkelanjutan sambil saling mengkritisi satu terhadap yang lain.

\section{Metapragmatik dalam Bahasa Ritual}

Dalam suara gembala Majelis Sinode GMIT terkait perayaan Bulan Bahasa dan Budaya, Mery Kolimon menegaskan tentang tiga aspek penting. Pertama, bahasa merupakan pemberian Tuhan yang mesti digunakan untuk membangun komunikasi memperteguh relasi dan mempekuat komimten kemanusiaan. Kedua, terjadinya degradasi nilai dalam penggunaan bahasa ibu. Ketiga, perjumpaan Injil dan adat istiadat. ${ }^{25}$ Ketiga catatan di atas disampaikan dalam rangka memberikan "pembobotan" teologis terhadap perayaan Bulan Bahasa dan Budaya. Dari aspek antropologi linguistik, pembobotan teologi tersebut dimaknai sebagai metapragmatik. Metapragmatik adalah gerakan tubuh yang dilakukan oleh seseorang kepada orang lain untuk maksud tertentu, sehingga orang lain yang melihat gerak tubuh itu terkesan diminta untuk melakukan sesuatu yang diinginkan oleh si penggerak tubuh. ${ }^{26}$ Metapragmatik menjadi penting, oleh karena perayaan Bulan Bahasa dan Budaya didesain untuk "menari" di sekitar pelataran mezbah sambil menyampaikan pesan "di luar mezbah". Artinya, pesan-pesan kearifan lokal disampaikan melalui gerakan tubuh, tarian, puisi, pantun dan ornament tradisional lainnya. Dalam konteks ini, dimensi mitos tidak terelakkan. Karena itu, perlu memaknai apa yang disampaikan oleh Mircea Eliade, bahwa jika orang harus menghadapi kesulitan dalam menembus makna yang dalam atas simbol, mitos dan ritus, orang tidak dapat melakukan apa-apa kecuali bahwa makna ini menunjukkan kesadaran atas situasi tertentu di dalam kosmos. ${ }^{27}$

Dalam kesadaran, bahwa banyak perintah Tuhan yang disampaikan melalui cerita atau kisah, ${ }^{28}$ maka peran bahasa ritual yang mengarahkan kita pada dimensi metapragmatik menjadi "pembawa pesan" (dimensi hermeneutik) ilahi. Bahasa ritual, sebagaimana disampaikan Manafe, tidak hanya berfungsi sebagai pembawa pesan secara an sich, tetapi lebih kepada proses dialektika kosmis yang berperan sebagai penata keseimbangan antara manusia, sesama, alam dan yang ilahi. Proses dielaktika ini yang dieksplorasi dalam frame liturgis oleh GMIT dalam perayaan Bulan Bahasa dan Budaya. Dalam dialektika tersebut, narasi-narasi bela-rasa dilakonkan melalui busana adat, tarian, lagu, puisi bahkan ornamen

\footnotetext{
${ }^{24}$ Gregor Neonbasu, Sebuah Agenda... xxi.

25 Secara lengkap materi Suara Gembala Majelis Sinode GMIT dapat diakses melalui https://www.youtube.com/watch?v=7Sm2hKIHUE4Et=4s

26 Ade Solihat, Memahami Bahasa Agama dalam Perspektif Antropologi, dalam Tony Rudyansjah (Peny.) Antropologi Agama, Wacana-wacana Mutakhir dalam Kajian Religi dan Budaya, (Jakarta: UI Press, 2012), 71.

${ }^{27}$ Mircea Eliade, Mitos..., hal. 3.

28 Solihat, Memahami..., hal. 71 .
} 
liturgis. Seruan dan syukur disampaikan melalui kisah yang dapat menggugah umat untuk melihat dirinya sebagai bagian dari ciptaan yang mesti berlaku adil begi segenap ciptaan lainnya. Dalam proses itu, nilai-nilai komunikasi yang muncul adalah keterbukaan (openes), kebenaran (truthfulness), penghargaan (respect), kerjasama (cooperation), kesepahaman (mutual understanding), penyesuaian (adaptability), kesantunan (modesty), kewajaran (fairness), kepercayaan (trust), nilai berimbang sara (empati, toleransi dan solidaritas). ${ }^{29}$ Nilai-nilai ini diperankan secara atraktif sebagai ekspresi kebertuhanan warga GMIT.

Menurut Komarudin Hidayat, sebagaimana dikutip Ade Solihat, mengemukakan dua perspektif dalam memaknai bahasa agama. Yang pertama adalah theo-oriented, yakni memandang bahasa sebagai kalam ilahi yang kemudian diabadikan dalam Kitab Suci; sedangkan yang kedua adalah anthropo-oriented, yang memandang bahasa agama sebagai ungkapan serta perilaku manusia atau sekelompok manusia. ${ }^{30}$ Kedua orientasi ini dapat didekati dengan pendekatan bahasa agama. Pendekatan bahasa agama tidak serta merta berbicara secara an sich tentang "bahasa langit", melainkan berbicara tentang norma, perilaku, dan idiologi. Solihat menjelaskan, bahwa bahasa agama menitikberatkan pada forma bahasa agama (termasuk bentuk dan deiksi) dan yang menitikberatkan pada isi (semantic-termasuk budaya dan idiologi). ${ }^{31}$ Penekanan ini hendak mempertegas bahwa bahasa agama seringkali dimaknai dengan pendekatan linguistik yang bersifat sakral dan sebaliknya yang menggunakan simbol bahasa sehari-hari dimaknai secara profan. ${ }^{32}$ Dalam kaitan dengan upaya menjembatani "kegundahan Ba'i Ndu" dan suasana sukacita Silube'i dalam mengikuti perayaan Bulan Bahasa dan Budaya dengan eksplorasi etnis Rote, berikut beberapa catatan yang perlu direfleksikan.

Pertama, pendekatan simbolik. Terdapat dua simbol yang menguat dalam perayaan tersebut. Simbol adat (tradisi) dan simbol kekristenan. Jika didekati dari aspek linguistik sebagaimana dikemukakan oleh Solihat, maka dengan mudah kita menyatakan, bahwa ada simbol profan dan simbol sakral. Walau demikian, ketika kita masuk jauh lebih ke aspek pemaknaan, maka simbol-simbol yang digunakan tidak hanya terbatas pada aspek simbol, tetapi lebih kepada merefleksikan makna simbol-simbol tersebut. Dalam tataran ini Solihat mempertegas pembedaannya dengan melihat aspek karakteristik dari bahasa. Jika bahasa keseharian memperhitungkan efektifitas dan ekonomi bahasa, maka bahasa agama justru memperlihatkan pengulangan-pengulangan.33 Simbol-simbol yang digunakan dalam perayaan Bulan Bahasa dan Budaya adalah simbol tradisi yang digunakan untuk memohon dalam format sakral, sehingga aspek yang ditekankan oleh Solihat dapat dimaknai sebagai "jalan tengah" merawat kegundahan yang dialami oleh Ba'i Ndu.

Kedua, pendekatan dialogis-pastoral. Pendekatan ini sangat umum dijumpai. Walau demikian, pendekatan ini justru yang sering diabaikan. Aspek metapragmatik yang dijumpai dalam ajakan melalui pantun dan syair yang dilakoni dalam pementasan tarian saat ibadah merupakan ekspresi dialogis-pastoral. Aspek ini mesti dimaknai dari sudut pantang keteraturan dan keseimbangan. Ebenhaizer I. Nuban Timo menggunakan istilah yang sangat sederhana unutk memaknai aspek keteraturan dalam masyarakat adat, yakni "mencari dan menemukan makna Allah dalam budaya. ${ }^{34}$ Mencari dan menemukan makna kehadiran Allah dalam budaya dikerjakan dalam rangka kembali kepada keteraturan yang telah Allah wujudkan dalam kisah penciptaan (Kej. 1). Berteriak sambil melompat saat

\footnotetext{
${ }^{29}$ Venus, Komunikasi..., hal.116 -128.

30 Solihat, Memahami..., hal. 66.

31 Solihat, Memahami..., 67.

32 Solihat, Memahami..., 68.

33 Solihat, Memahami..., 69.

${ }^{34}$ Nuban Timo, Sidik Jari... v.
} 
melakonkan seorang tokoh dalam tarian ketika ibadah berlangsung merupakan ekpresi keteraturan yang menghadirkan rasa kagum, takjub dan pengakuan. Suasana kekaguman, ketakjuban dan pengakuan kemudian diceritakan terus-menerus kepada setiap warga untuk memahami bahwa "tarian bumi" dijumpai dalam "rumah Tuhan." Di sinilah aspek dialogispastoral tampak dalam pendekatan ini.

\section{Tarian Langit-Bumi dan Keseimbangan}

Dalam filsafat komunikasi dikenal istilah etnofilosofi. Istilah ini kemudian didefenisikan oleh Marylin Holly, lalu dikutip oleh Antar Venus, sebagai filsafat lokal (indigenous philosophical systems) yang berbasis pada cerita rakyat (folklore), mitos, ungkapan dan peribahasa. ${ }^{35}$ Basis filosofi tersebut kemudian membentuk cara pandang masyarakat lalu dikomunikasikan melalui berbagai simbol. Dalam konsep mitos, Eliade menempatkan pembebasan waktu profan dan projeksi individu dalam frame ketika individu benar-benar merupakan dirinya sendiri melalui ritual dan atau aksi. ${ }^{36}$ Artinya, ketika ekpresi manusia dipentaskan melalui syair, tari dan peribahasa dimaknai sebagai instrumen terpenting dalam membangun hubungan, memelihara harmoni sosial dan menjaga kelangsungan hidup bersama. ${ }^{37}$ Syair, tari dan peribahasa dalam liturgi Bulan Bahasa dan Budaya GMIT secara an sich tidak dibingkai dalam lingkaran tata ibadah. Tetapi, spirit, ekspresi, kostum dan lakon serta tutur kata menyampaikan pesan-pesan ilahi yang telah terpelihara sejak berabad-abad lamanya. Disinilah kita kemudian menyaksikan tarian "langit-bumi" dalam ruang ibadah GMIT. Ada kesadaran bahwa sekian lama gong dan sasando ingin dijadikan sebagai pengiring mazmur dalam ibadah, namun panggung untuk gong dan sasando diformat sebagai "yang berasal dari dunia" dan karena itu dianggap kafir. Klaim itu terpelihara cukup lama. Gong dan sasando pun menari di samping gereja. Keduanya takut menuju ke gereja. Kini saatnya, keduanya diajak menari di hadapan mezbah Tuhan. Keduanya diajak untuk memberi nilai dan pesan agar warga GMIT yang terlelap bangun dan menari mengikuti irama gong dan sasando. Saat ajakan itu disampaikan, disitulah kita diajak untuk menciptakan keseimbangan.

Keseimbangan menjadi tema penting pada beberapa daerah dalam lingkup GMIT. Ebenhaizer I. Nuban Timo menjadikan ike-suti dan suni-auni sebagai prototype dalam membangun keseimbangan. ${ }^{38}$ ike-suti merupakan alat tradisional yang digunakan oleh perempuan dewasa Timor untuk memintal kapas, lalu mengolahnya menjadi tenunan sesuai dengan corak motif dari setiap marga yang menenun. Sementara suni-auni merupakan alat untuk berburu, berkebun, membangun rumah dan berperang melawan musuh. Suni adalah kata untuk pedang, sedangkan auni adalah tombak. ${ }^{39}$ Bagi masyarakat Timor di daerahdaerah tertentu, sebutan untuk benda-benda tersebut tidak bisa dipisahkan satu terhadap yan lain. Ketika menyebut ike, maka harus dilanjutkan dengan suti. Begitu juga, suni. Penyebutan suni selalu dilanjutkan dengan auni.

Dari benda-benda tersebut, Nuban Timo kemudian mengemukakan beberapa pola hidup dan tingkah laku sosial, spiritualitas dan pemahaman teologis masyarakat meto sebagai cerminan warga GMIT yang menempatkan keseimbangan sebagai salah satu ekpresi dalam beragam tarian selama Bulan Bahasa dan Budaya. Pola hidup dan tingkah laku sosial serta spiritualitas yang dimaksudkan adalah perempuan dan laki-laki sebagai mitra yang sejajar, perempuan dan laki-laki sebagai homo laborans (arti diri atau makna hidup),

\footnotetext{
35 Venus, Filsafat..., 2.

36 Eliade, Mitos..., 36.

37 Venus, Filsafat,..., 2.

${ }^{38}$ Nuban Timo, Sidik Jari ..., 3, 4 .

${ }^{39}$ Ibid., 4.
} 
perempuan dan laki-laki sebagai homo ludens (manusia yang tertawa, orang-orang yang bersukacita), laki-laki dan perempuan sebagai homo religious, laki-laki dan perempuan sebagai pencinta lingkungan, laki-laki dan peremuan percaya akan kehidupan sesudah kematin. 40

Keenam pola hidup ini yang direfleksikan secara baik dalam perayaan Bulan Bahasa dan Budaya. Keenam pola ini pula yang dipentaskan melalui tarian, busana, ekspresi, doa, litany, mazmur dan berbagai bentuk aktualisasi diri lainnya. Keenam pola ini menekankan keseimbangan. Disinilah makna hakiki dari "tarian langit-bumi" yang dipentaskan selama Bulan Bahasa dan Budaya. Manusia sebagai ciptaan yang terdiri dari laki-laki dan perempuan dimaknai sebagai makluk yang sejajar satu terhadap yang lain. Tidak boleh ada dominasi laki-laki atas perempuan. Begitu juga tidak boleh ada eksploitasi terhadap alam. Manusia perlu menata hidupnya agar tercipta keseimbangan baik antarsesama manusia maupun dengan alam. Salah satu sumbangsih perayaan Bulan Bahasa dan Budaya adalah penguatan nilai-nilai kemanusiaan yang menekankan pada aspek keseimbangan.

\section{Kesimpulan}

\section{Perlu Konsistensi: Sebuah Catatan Kritis}

Perayaan Bulan Bahasa dan Budaya telah berlangsung. Beragam tanggapan telah disampaikan. Banyak kalangan yang mengapresiasi. Saya juga senang dengan "keberanian" GMIT memberikan panggung kepada "penari-penari lokal" untuk "manggung"di gereja. Mungkin selama ini mereka tidak diberi kesempatan manggung, baik dalam perhelatan adat, pemerintah apalagi gereja. Walau demikian, perayaan ini bukan tanpa catatan evaluatif. Salah satu yang hendak diangkat dalam tulisan ini adalah terkait konsistensi dalam menggunakan produk persidangan sinode. Hasil keputusan sinode secara jelas mencatat, bahwa bulan Mei ditetapkan sebagai Bulan Bahasa, bukan Bulan Bahasa dan Budaya. Itu berarti, terdapat penambahan kata "budaya" dalam nomenklatur yang telah disepakati bersama. Catatan atas penambahan kata "budaya" terkesan prematur dan tidak substantif, tetapi bagi saya ini justru penting. Dalam sejarah bangsa kita terkait perumusan Sila Pertama dari Pancasila (Ketuhan Yang Maha Esa), terdapat beberapa kata yang dikeluarkan dan bukankah itu yang menjadi "penentu" bagi kebhinekaan. Dalam konteks ini, penambahan kata "budaya" dalam hasil keputusan yang dihasilkan secara kolektif mesti dikritisi.

Catatan berikutnya terkait konsistensi adalah perlu adanya naskah teologis. Ini penting, semangat misi tidak kebablasan. Artinya, semangat misiologis itu penting, tetapi perlu pendasaran-pendasaran yang bersifat teologis. Jika tidak, maka ekpresi-ekpresi keberimanan akan bias terminologi. Akselesari memang penting, tetapi akselerasi membutuhkan pendasaran, sehingga akselerasi-akselerasi tidak terjun bebas sehingga kemudian menimbulkan kekacauan.

Dialog yang emansipatif dan pendampingan yang berkelanjutan sebagai langkah pemberdayaan ekonomi jemaat perlu mendapat perhatian ekstra. Artinya, perayaan yang membutuhkan pakaian adat, makanan lokal, properti berbahan lokal sebenarnya memberi peluang bagi pengembangan ekonomi jemaat. Karena itu, perlu dialog yang bersifat emansipatif dengan para penenun, para petani, para pelukis tradisional dan penutur seni tradisional dalam penataan seni dan budaya kita. Mereka perlu didampingi dan diberi ruang untuk mengembangkan kreatifitas mereka. Pendampingan dan pengembangan tidak hanya sebatas slogan selama perayaan Bulan Bahasa dan Budaya, tetapi dikonkritkan melalui pembentukan sanggar tarian dan sanggar tenunan yang menjadi wadah bagi warga gereja untuk mengembangkan potensi yan dimiliki. Disinilah sumbangsih perayaan Bulan Bahasa dan Budaya GMIT bagi warganya.

${ }^{40}$ Ibid., 6. 


\section{Rujukan}

Eliade, Mircea. Mitos, Gerak Kembali Yang Abadi, Kosmos dan Sejarah. Terj. Cuk Ananta; Yogyakarta: IKON TERALITERA, 2002.

Katha Ratna, Nyoman.Metodologi Penelitian, Kajian Budaya dan Ilmu Sosial Humaniora Pada Umumnya. Yogyakarta: Pustaka Pelajar, 2016.

Ketetapan Sinode Gereja Masehi Injili di Timor Nomor 14/TAP/SIN-GMIT/XXXI/2007 tentang Peraturan Ibadah dan Atribut. Kupang: Majelis Sinode GMIT, 2007.

Kristiyanto, A. Eddy. Rumusan dan Teologi Credo, dalam Josep Ferry Susanto (Ed.) Credo dan Relevansinya, Ulasan Komprehensif Rumusan Iman Kristiani. Jakarta: Obor, 2014.

Mae, Ramona Mathias, Pengembangan Model Tarian Bonet untuk Kebugaran Jasmani dalam Pembelajaran Penjasorkes di Sekolah Dasar, dalam Jurnal Keolahragaan, 5 (1), 2017

Manafe, Yermia Djefri. Cara Pandang (World View) Orang Atoni Pah Meto dalam Perspektif Komunikasi Ritual, dalam Jurnal Scriptura, Vol. 6. No. 2, Desember 2016. Surabaya: UK Petra, 2016.

Nayuf, Henderikus. Allah Merumuskan Diri-Nya, Kajian Filsafat-Teologis tentang Pengakuan Iman GMIT dan Relevansi Trinitarian bagi Kemandirian Teologi di GMIT. Makassar: STT INTIM, 2009.

Neonbasu, Gregor. Sebuah Agenda untuk Mengkaji Timor, dalam Gregor Neonbasu (Peny.) Kebudayaan, Sebuah Agenda dalam Bingkai Pulau Timor dan Sekitarnya. Jakarta: Gramedia Pustaka Utama, 2009.

Ndolu, Nelci Nafalia dan Marsi Bombongan Rantesalu. “Makna Tanah Leluhur Bagi Naomi Berdasarkan Teks Rut 1:1-22." Jurnal Ilmiah Religiosity Entity Humanity (JIREH) 1, no. 1 (2019): 87-98. https://ojs-jireh.org/index.php/jireh/article/view/9.

Nuban Timo, Ebenhaizer I. Sidik Jari Allah dalam Budaya, Upaya Menjajaki Makna ALLAH dalam Perangkat Budaya Suku-suku di Nusa Tenggara Timur. Maumere: Ledalero, 2005. - Mitos Asal-Usul Nama Pulau Timor, Paper yang diakses melalui https://www.academia.edu/30987663/Mitos_Asal_Usul_Nama_Pulau_Timor. https: / / www.youtube.com/watch?v=7Sm2hKIHUE4\&t=4s

Paul Bola, Kebaktian ko Pertunjukan, dalam sinodegmit.or.id, 18 Mei 2019.

Pokok-pokok Eklesiologi GMIT. Kupang: Majelis Sinode GMIT, 2011.

Solihat, Ade. Memahami Bahasa Agama dalam Perspektif Antropologi, dalam Tony Rudyansjah (Peny.) Antropologi Agama, Wacana-wacana Mutakhir dalam Kajian Religi dan Budaya. Jakarta: UI Press, 2012.

Un, Hildegardis, Nilai-nilai dan Makna Tarian Tebe di Nusa Tenggara Timur, Desa Kusa, Kecamatan Malaka Timur, Kabupaten Malaka, dalam Simki-Pedagogia Vol. 01 No. 08 Tahun 2017. Kediri: Universitas Nusantara PGRI, 2017.

Venus, Antar. Filsafat Komunikasi Masyarakat Melayu. Bandung: Simbiosa Rekatama Media, 2015. 